\title{
NEW OUTBREAK OF SWINE INFLUENZA IN THE CZECH REPUBLIC
}

J. BUCHTA ${ }^{1}$, P. LÁNY ${ }^{1}$, M. ŽIŽLAVSKÝ ${ }^{2}$, J. THURNVALDOVÁ ${ }^{2}$, Z. POSPÍŠIL ${ }^{1}$

${ }^{1}$ Department of Infectious Diseases and Veterinary Epidemiology, University of Veterinary and Pharmaceutical Sciences, Brno, ${ }^{2}$ SEVARON Consulting, Ltd., Brno, Czech Republic

Received May 25, 2001

Accepted August 28, 2001

\section{Abstract}

Buchta J., P. Lány, M. Žižlavský, J. Thurnvaldová, Z. Pospíšil: New Outbreak of Swine Influenza in the Czech Republic. Acta Vet. Brno 2001, 70: 321-325.

Swine influenza has not caused any serious health or economic losses in the Czech Republic since the end of the 1960's. No manifestations of this disease have been confirmed in pig herds during the last ten years, with the exception of a single virus isolation in 1992 and detection of antibodies against human influenza in 1996 following the 1995 human epidemic. In 2000, swine influenza virus was isolated from feeder pigs on a large farm with nearly 10000 animals. The infection was determined by cultivation of nasal swabs in the allantoid sac of nine-day-old chick embryos and by serological examination in the haemagglutination-inhibition test. The virus isolated from the chick embryos was tested against specific antisera and classified as possessing type $\mathrm{H} 1$ haemagglutinin. The cultivation finding was confirmed by a significant increase in antibody levels found in sera collected three weeks after the outbreak of infection. The reactions of these sera with selected antigens showed that the virus was closely related to the virus (A/sw/Brno/92) isolated from a single outbreak of swine influenza in 1992. Our isolate was designated $\mathrm{A} / \mathrm{sw} / \mathrm{Brno} / 1 / 2000$.

Influenza, pig, virus isolation, haemagglutinin, H1N1, H3N2

Influenza, a viral infection of the respiratory system spread world - wide in humans as well as animals, is caused by single-stranded RNA viruses of the family Orthomyxoviridae. Each host is usually infected by specific strains, but interspecies transmission sometimes occurs. On the basis of antigenic properties of their nucleoprotein, these viruses are identified as types A, B or C. Type A viruses, which have mainly been isolated from farm animals, are further classified according to their surface antigens termed haemagglutinin and neuramidase. Up to the present, 15 haemagglutinin and 9 neuramidase types have been distinguished (Scholtis sek et al. 2000).

The influenza viruses most commonly isolated from pigs all over the world are those bearing either H1N1 or H3N2 surface antigens or, occasionally, their combination. Three different HA/NA configurations or subtypes of swine influenza, i.e., H1N1, H3N2 and H1N2, have so far been isolated in Europe (Lange 2000).

The classical H1N1 subtype is widely spread mainly in the USA and Asia. In Europe, including the Czech Republic, it was prevailing in the 1950s and 1960s, with the exception of Great Britain where it remained predominant till 1990s, and was subsequently replaced by an avian variant of the H1N1 subtype transmitted from wild birds (Arora et al. 1997). This variant infected our pig population probably about 1979 and, in the following years, it was responsible for a series of epidemics on the Continent and gradually became established instead of the original H1N1 subtype.

The H3N2 subtype of influenza virus was first isolated from pigs in 1969 after the 1968 human pandemic (Kundin 1970); since then, at irregular intervals, it has been isolated from large pig herds all over Europe and, most recently, also on the American Continent

Address for correspondence:

MVDr. Josef Buchta

Department of Infectious Diseases and Veterinary Epidemiology

University of Veterinary and Pharmaceutical Sciences

Palackého 1-3, Brno, Czech Republic
Phone: +420541562310

Fax: +420541562014

http://www.vfu.cz/acta-vet/actavet.htm 
(Karasin et al. 2000). The H1N2 subtype, since 1994 isolated in France (Gourreau 1994), Great Britain (B achman 1989) and Japan (Ito et al. 1998), has probably arisen by reassortment of the human $\mathrm{H} 1 \mathrm{~N} 1$ and swine $\mathrm{H} 3 \mathrm{~N} 2$ viruses.

It has been observed that clinical signs of the disease caused by European viruses are generally milder that those caused by Asian viruses (Easterday et al. 1992).

Although swine influenza is, at present, a rare infection in the Czech Republic, in the 1950's and 60's it accounted for high losses in large pig herds (Menšík 1960; Tůmová et al. 1976). The last isolation of swine influenza virus was reported in 1992 and the serological response of pigs to a human influenza epidemic was recorded in 1996 (Pospíšil et al. 1997). The lack of information on the epidemiological situation in our pig herds was the reason for a survey of the current status of swine influenza in the Czech Republic. The results of the finding of an influenza infection on one farm are reported in this study.

\section{Materials and Methods}

Epidemiological findings

An outbreak of respiratory disease with clinical signs resembling influenza, which spread on the whole premises within four days, was reported on a farm breeding feeder swine in July 2000. The farm had 9849 pigs housed in four houses, each divided into separate halls that were further partitioned into individual pens with about ten pigs in each. The pigs came from three different breeding stocks. After transfer to the farm, all pigs were immunised by a commercial vaccine against Mycoplasma pneumoniae and a vaccine based on Actinobacillus pleuropneumoniae isolated on that farm.

\section{Collection of materials}

Nasal swabs were collected from pigs with pronounced clinical signs. The swabs were placed in $2 \mathrm{ml}$ transport medium based on 1 litre of E-MEM solution, according to Eagle, with Earle salts (Sevapharma, a.s. Praha) supplemented with vitamins (2.5 ml VIT MEM, Sevac), glutamin (6 ml, GLUTAMIN GL, Sevac) and non-essential amino acids (2.5 ml, NEA, Sevac) at $\mathrm{pH} 7.5$ (adjusted with $15 \mathrm{ml} 7.5 \% \mathrm{NaHCO}_{3}$, Sevac); subsequently, 1100000 I.U. G Penicillin (Biotika) and $440 \mathrm{mg}$ Gentamicin (Lek) were added. The samples were delivered to the laboratory at $4{ }^{\circ} \mathrm{C}$ and immediately inoculated. The materials to be used later were stored at $-80{ }^{\circ} \mathrm{C}$.

Paired serum samples were taken for serological examination from each pig; the first sample was taken at the time of nasal swab collection, the second three weeks later.

Virus isolation and characterisation

Nasal swab samples $(0.2 \mathrm{ml})$ were inoculated into the allantoid sacs of nine-day-old chick embryos. The eggs were incubated for 3 days at $37^{\circ} \mathrm{C}$ and checked for viability every day. Dead embryos were stored at $4{ }^{\circ} \mathrm{C}$ and living embryos were devitalised, after incubation, for at least $12 \mathrm{~h}$ at $4{ }^{\circ} \mathrm{C}$. Altogether three passages were carried out in chick embryos. Allantoid fluid from all embryos was examined by the haemagglutination test.

Haemagglutination test

The test was carried out in U-bottom microtitre plates. Serial twofold dilutions $(0.05 \mathrm{ml})$ of the allantoid fluid were mixed with equal volumes of $1 \%$ chicken erythrocyte suspension. The plates were allowed to stand at room temperature and the results were read after $60 \mathrm{~min}$. If the result was positive, the virus type was identified using specific antisera. Poultry antisera against A/sw/Brno/1/92 and A/sw/Gent/132/86 viruses were prepared at our department by intravenous administration of the viruses to hens (Tůmová 1985). Guinea pig antiserum against A/sw/Germany/514/84 was kindly donated by the Veterinary University of Vienna.

Antibody determination

The paired serum samples were examined by the haemagglutination-inhibition test (HIT). To eliminate nonspecific reactions, the sera were mixed with poultry erythrocytes ( $1 \%$ suspension), allowed to stand for 30 min and then treated with receptor-destroying enzyme (Seiken) at room temperature overnight. Before the sera were used in the test, the enzyme was inactivated by exposure to $56^{\circ} \mathrm{C}$ for $30 \mathrm{~min}$.

Strains used

The virus strains used in the haemagglutination-inhibition test were as follows: A/sw/Křeptov/63, $\mathrm{A} / \mathrm{sw} / \mathrm{Gent} / 132 / 86, \mathrm{~A} / \mathrm{sw} / \mathrm{Brno} / 1 / 92$ and the newly isolated strain designated $\mathrm{A} / \mathrm{sw} / \mathrm{Brno} / 1 / 2000$. 
Haemagglutination-inhibition test

HIT was carried out in U-bottom microtitre plates. Serial dilutions of the starting, $25 \mu$ l- volume of the serum examined were mixed with equal volumes of allantoid fluid containing four haemagglutination-inhibition units of the virus and incubated at room temperature for $40 \mathrm{~min}$. Subsequently, $0.05 \mathrm{ml}$ of $1 \%$ chicken erythrocytes were added. The results were read after 40 to $60 \mathrm{~min}$ at laboratory temperature. The haemagglutination-inhibition titre was expressed as the reciprocal of the highest serum dilution at which complete inhibition of haemagglutination occurred (Pospíšil et al. 1991).

\section{Results}

The infectious disease in the herd investigated showed almost 100\% morbidity but a very low mortality that only slightly exceeded the mortality before the flare-up of disease. The clinical signs were characterised by frequent sneezing, dry cough, anorexia and apathy with temperature running up to $41^{\circ} \mathrm{C}$. They usually subsided within three or four days.

An agent agglutinating chicken erythrocytes was found in the first passage of nasal swab samples at titre levels of 1:8 to 1:64; on second and third passages, there was an increase in titre up to 1:512 and 1:4096, respectively.

On the basis of examination by the specific antisera in HIT, the virus was classified as the H1Nx type and designated A/sw/Brno/1/2000 (Table 1).

Increased levels of antibodies against our isolate in serum samples collected from pigs

Table 1

Serotyping of the $\mathrm{A} / \mathrm{sw} / \mathrm{Brno} / 1 / 2000$

\begin{tabular}{|c|c|c|c|}
\hline \multirow[b]{2}{*}{ Virus } & \multicolumn{3}{|c|}{ Antiserum } \\
\hline & A/sw/Gent/132/86 & A/sw/Germany/514/84 & $\mathrm{A} / \mathrm{sw} / \mathrm{Brno} / 753 / 92$ \\
\hline $\begin{array}{l}\text { A/sw/Gent/132/86 } \\
(\mathrm{H} 3 \mathrm{~N} 2)\end{array}$ & $1: 64$ & $x_{1}$ & 0 \\
\hline $\begin{array}{l}\text { A/sw/Germany/514/84 } \\
\text { (H1N1) }\end{array}$ & 0 & $1: 512$ & $1: 128$ \\
\hline $\begin{array}{l}\text { A/sw/Brno/92 } \\
(\mathrm{H} 1 \mathrm{Nx})\end{array}$ & 0 & $1: 256$ & $1: 512$ \\
\hline $\begin{array}{l}\text { A/sw/Křeptov/63 } \\
\text { (H1N1) }\end{array}$ & 0 & $1: 128$ & $1: 256$ \\
\hline $\begin{array}{l}\text { A/sw/Brno/1/2000 } \\
(\mathrm{H} 1 \mathrm{Nx})\end{array}$ & 0 & $1: 32$ & $1: 64$ \\
\hline
\end{tabular}

Table 2

Antibody titre levels against selected antigens in paired serum samples collected from the infected pigs

\begin{tabular}{|c|c|c|c|c|c|c|c|c|}
\hline \multirow{2}{*}{$\begin{array}{c}\text { Serum } \\
\text { No. }\end{array}$} & \multicolumn{9}{|c|}{ Virus } \\
\cline { 2 - 8 } & \multicolumn{2}{|c|}{ A/sw/Gent/132/86 } & \multicolumn{2}{|c|}{ A/sw/Křptov/63 } & \multicolumn{2}{|c|}{ A/sw/Brno/92 } & \multicolumn{2}{c|}{ A/sw/Brno/1/2000 } \\
\cline { 2 - 8 } & Sample 1 & Sample 2 & Sample 1 & Sample 2 & Sample 1 & Sample 2 & Sample 1 & Sample 2 \\
\hline 1 & $<1: 8$ & $<1: 8$ & $<1: 8$ & $<1: 8$ & $<1: 8$ & $1: 128$ & $1: 512$ & $1: 512$ \\
\hline 2 & $<1: 8$ & $<1: 8$ & $<1: 8$ & $<1: 8$ & $<1: 8$ & $1: 64$ & $<1: 8$ & $1: 256$ \\
\hline 3 & $<1: 8$ & $<1: 8$ & $<1: 8$ & $<1: 8$ & $<1: 8$ & $1: 128$ & $1: 128$ & $1: 256$ \\
\hline 4 & $<1: 8$ & $1: 64$ & $<1: 8$ & $<1: 8$ & $<1: 8$ & $1: 64$ & $1: 128$ & $1: 512$ \\
\hline 5 & $1: 32$ & $1: 16$ & $<1: 8$ & $1: 32$ & $1: 32$ & $1: 512$ & $1: 128$ & $1: 512$ \\
\hline 6 & $<1: 8$ & $<1: 8$ & $<1: 8$ & $<1: 8$ & $<1: 8$ & $1: 128$ & $1: 32$ & $1: 128$ \\
\hline 7 & $<1: 8$ & $<1: 8$ & $<1: 8$ & $<1: 8$ & $1: 64$ & $1: 64$ & $1: 64$ & $1: 256$ \\
\hline 8 & $<1: 8$ & $<1: 8$ & $<1: 8$ & $<1: 8$ & $<1: 8$ & $1: 32$ & $1: 32$ & $1: 512$ \\
\hline 9 & $1: 32$ & $<1: 8$ & $<1: 8$ & $1: 16$ & $1: 128$ & $1: 64$ & $1: 512$ & $1: 128$ \\
\hline 10 & $<1: 8$ & $<1: 8$ & $<1: 8$ & $<1: 8$ & $<1: 8$ & $1: 32$ & $1: 128$ & $1: 512$ \\
\hline
\end{tabular}


with obvious clinical signs and a four- to six-fold increase in titre levels in paired samples collected three weeks later demonstrated that the infection was caused by the $\mathrm{A} / \mathrm{sw} / \mathrm{Brno} / 1 / 2000$ virus. No increase in antibody titres was found, with only one exception, against the $\mathrm{H} 3$ haemagglutinin of $\mathrm{A} / \mathrm{sw} / \mathrm{Gent} / 132 / 86$ nor even against the $\mathrm{H} 1$ haemagglutinin of $\mathrm{A} / \mathrm{sw} / \mathrm{Krreptov} / 63$. On the other hand, at least a four-fold increase in antibody levels was recorded against the $\mathrm{H} 1$ haemagglutinin of the strain $\mathrm{A} / \mathrm{sw} / \mathrm{Brno} / 92$, which implied that there was a relationship between the influenza virus strain isolated from the diseased herd and the A/sw/Brno/92 strain (Table 2).

\section{Discussion}

The isolation of virus and detection of a significant increase in antibody levels provided evidence that the respiratory infection that broke out in pigs on one farm in 2000 was caused by swine influenza virus. The previous outbreak of swine influenza in the Czech Republic had been recorded in 1992 (Š esták 1992, personal communication). In 1996, antibodies against the $\mathrm{H} 3$ haemagglutinin were detected in several of our pig herds; they were found to be related to the human influenza epidemic caused by the strain A/Praha/625/95 (H3N2) isolated in December 1995 (Pospíšil et al. 1997). Generally, outbreaks of swine influenza in the Czech Republic have been less frequent than in West European countries (Loeffen et al. 1999; Brown et al. 1995; Gutierrez Martin et al. 2000) where influenza viruses with the $\mathrm{H} 3$ and avian $\mathrm{H} 1$ haemagglutinins and a new H1N2 strain have been identified (Reeth et al. 2000).

The strains isolated in this study and tested by HIT against poultry and guinea pig antisera were classified as an influenza virus with type $\mathrm{H} 1$ haemagglutinin. The results of serotyping showed that the poultry antisera used in this study were sensitive enough to distinguish between type $\mathrm{H} 1$ and type $\mathrm{H} 3$ haemagglutinins. Identification of the virus by means of antisera showed that the causative agent was not related to the classical swine influenza virus but was similar to the strain $\mathrm{A} / \mathrm{sw} / \mathrm{Brno} / 92(\mathrm{H} 1 \mathrm{~N} 1)$.

The outbreak of infection occurred suddenly. The farm was situated in an isolated area several kilometres away from the nearest village, with no other pig farm in the vicinity. The commuting farm workers took precautions and changed their cloths before attending to animals. Therefore, it was concluded that the source of infection came from one of the farms supplying the breeding stock, although none of them had reported any infection.

It will be possible to evaluate the epidemiological significance of this finding only after the isolates have been studied in more detail by tests with ferret antisera and by molecular biology methods. These results will enable us to assess epidemiological risks of swine influenza entry into herds in case further influenza viruses are detected, and to protect the herd by vaccination, where indicated. Even without these results, however, awareness should be maintained that danger of swine influenza outbreaks in our pig herds is real.

\section{Nový výskyt influenzy prasat v České republice}

Influenza prasat nezpůsobovala od konce 60. let v České republice velké zdravotní a ekonomické problémy. Mimo ojedinělé izolace influenzového viru v roce 1992 a odrazu epidemie humánní influenzy v některých chovech prasat v roce 1996, manifestovaného vzestupem hladin protilátek, nebyly $\mathrm{v}$ posledních deseti letech potvrzeny projevy tohoto onemocnění. V roce 2000 byl v České republice potvrzen nový výskyt viru influenzy prasat ve výkrmu na farmě o kapacitě blížící se 10000 kusům. Infekce byla prokazována kultivací nazálních výtěrů $\mathrm{v}$ alantoidním vaku desetidenních kurecích embryích a serologickým vyšetřením pomocí hemaglutinačně inhibičního testu. Z kuřecích embryí byl izolován influenzový virus, který byl typizací specifickými antiséry zařazen $\mathrm{k}$ virům s hemaglutininem 
H1. Kultivační nález byl potvrzen signifikantním vzestupem postinfekčních hladin protilátek. Reakce postinfekčních sér nemocných prasat s použitými viry ukázala velkou př́ibuznost $\mathrm{s}$ virem izolovaným v České republice v roce 1992. Pravděpodobným zdrojem nákazy ve výkrmu byl nákup malých selat $\mathrm{z}$ některého ze tří dodavatelských chovů.

\section{Acknowledgements}

The study was supported by grant No. 524/99/1226 from the Grant Agency of the Czech Republic and by a research plan (MSM 161700001) of the Ministry of Education, Youth and Physical Education of the Czech Republic.

\section{References}

ARORA, D. J. S., N' DIAYE, M., DEA, S. 1997: Genomic study of hemagglutinins of swine influenza (H1N1) viruses associated with acute and chronic respiratory diseases in pigs. Arch. Virol. 142:401-412

BACHMAN P. A. 1989: Swine influenza, In: PENSAERT, M. B.: Virus Infections of Porcine, Elsevier Science Publisher B. V., Amsterdam, pp. 193-207

BROWN, I. H., HARRIS, P. A., ALEXANDER, D. J. 1995: Serological studies of influenza viruses in pigs in Great Britain 1991-2. Epidemiology and Infection. 114:511-520

EASTERDAY, B. C., HINSHAW, V. S. 1992: Swine Influenza, In: Leman A. D. et al.: Diseases of swine, Iowa State Univ. Press, Ames, pp. 349-357

GOURREAU, J. M., KAISER, C., VALETTE, M., DOUGLAS, A. R., LABIE, J., AYMARD, M. 1994: Isolation of two H1N2 influenza viruses from swine in France. Arch. Virol. 135:365-382

GUTIERREZ MARTIN, C. B., RODRIGUEZ DELGADO, O., ALVAREZ NISTAL, D., DE LA PUENTE REDONDO, V. A., GARCIA RIOJA, F., MARTIN VICENTE, J., RODRIGUEZ FERRI, E. F. 2000: Simultaneous serological evidence of Actinobacillus pleuropneumoniae, PRRS, Aujeszky's disease and influenza viruses in Spanish finishing pigs. Res. Vet. Sci. 68:9-13

ITO, T., KAWAOKA, Y., VINES, A., ISHIKAWA, H., ASAI, T., KIDA, H. 1998: Continued circulation of reassortant H1N2 influenza viruses in pigs in Japan. Arch. Virol. 143:1773-1782

KARASIN, A. I., SCHUTTEN, M. M., COOPER, L. A., SMITH, C. B., SUBBARAO, K., ANDERSON, G. A., CARMAN, S., OLSEN, C.W. 2000: Genetic characterization of H3N2 influenza viruses isolated from pigs in North America, 1977-1999: evidence for wholly human and reassortant virus genotypes. Vir. Res. 68:71-85

KUNDIN, W. D. 1970: Hong Kong A-2 influenza virus infection among swine during a human epidemic in Taiwan. Nature 228: 857-867

LANGE, W. 2000: Pferde-influenza, Virologie, Epidemiologie, Klinik, Therapie und Prophylaxe. Parey, Berlin: $190 \mathrm{p}$.

LOEFFEN, W. L., KAMP, E. M., STOCKHOFE ZURWIEDEN, N., VAN NIEUWSTADT, A. P., BONGERS, J. H., HUNNEMAN, W. A., ELBERS, A. R., BAARS, J., NELL, T., VAN ZIJDERVELD, F. G. 1999: Survey of infectious agents involved in acute respiratory disease in finishing pigs. Vet. Rec. 145: 123-129

MENŠÍK, J. 1960: The production and dynamism of antibodies in swine influenza. Vet. Med. Praha 5: 599-610

POSPÍŠIL, Z., TƯMOVÁ, B., ULMANN, L., ZENDULKOVÁ D., FALTEJSEK J. 1991: Epizootics of equine influenza in Czechoslovakia caused by the type A/equi 2(H3N8), and the effects of vaccination. Acta Vet. Brno 60: $153-159$

POSPÍŠIL, Z., LÁNY, P., ZENDULKOVÁ, D., TƯMOVÁ B., JAHN P., ČÍHAL P. 1997: Surveillance of influenza virus in pigs and horses in the Czech Republic. Epidemiol. santé anim. 31-32: 39-42.

REETH, Van K., BROWN, I. H., PENSAERT, M. 2000: Isolations of H1N2 influenza A virus from pigs in Belgium. Vet. Rec. 146: 588-589

SCHOLTISSEK, C., HINSHAW, V., OLSEN, C. W., 2000: Influenza in Pigs and their Role as the Intermediate Host, In: NICHOLSON, K. G., WEBSTER, R. G., HAY, A. J.: Textbook of Influenza, Blackwell Science, Oxford, pp. 137-145

ŠESTÁK, K. 1992, personal communication

TŮMOVÁ, B., MENŠ́́K, J., ŠTUMPA, A., POSPÍŠIL, Z., FEDOVÁ, D. 1976: Serological evidence and isolation of a virus closely related to the human A/Hong Kong/68 (H3N2) strain in swine populations in Czechoslovakia in 1969-1972. Zbl. Vet-Med. 23B: 590-603

TƯMOVÁ, B. 1985: Laboratorní diagnostika chřipky. In: SYRU゚ČEK, L., et al.: Vyšetřovací metody virových onemocnění dýchacích cest. AVICENUM, Praha, pp. 75-99 